\title{
Literatura e memória: uma proposta de letramento literário para o conto popular no Ensino Fundamental
}

Edivana Cássia Munhoz Suriano

edivanamunhoz@yahoo.com.br Universidade Estadual de Maringá/ SEED, Maringá, Brasil.

Margarida da Silveira Corsi margaridacorsi33@hotmail.com Universidade Estadual de Maringá, Maringá, Brasil.

\begin{abstract}
RESUMO
No segmento do Ensino Fundamental, a divulgação do repertório folclórico pode ocorrer por meio da literatura infanto-juvenil, uma vez que é importante que crianças e jovens entrem em contato com histórias, causos e lendas a que seus ascendentes tiveram acesso. Por isso, o presente trabalho tem o objetivo de resgatar a importância dos causos, ou seja, das narrativas orais contadas e recontadas de geração em geração, seu possível significado à época e sua ressignificação no contexto atual. Sendo uma das funções da escola a de valorizar e divulgar a cultura oral, um dos exemplares mais singulares é o conto popular. Assim, para contribuir com o resgate da memória e da história literária, escolhemos o (re)conto "Uma lição no fazendeiro", do livro Causos de Pedro Malasartes, escrito por Júlio Emílio Braz e ilustrado por Anelise Zimmermann, para desenvolver uma proposta de letramento literário no ensino fundamental II. A fundamentação teórica deste trabalho baseou-se em Zilberman e Silva (1990), Silva (2009), Michelletti (2000), Cosson (2014) e Corsi (2015).
\end{abstract}

PALAVRAS-CHAVE: Letramento Literário. Cultura popular. Ensino. Reconto. 


\section{INTRODUÇÃO}

O folclore e a literatura popular estão na base da cultura brasileira bem como de diversos outros povos. Todo o legado folclórico-popular constituiu-se a partir da oralidade, apesar de esta ser, muitas vezes, esquecida em nome de uma cultura escrita e letrada. Tendo em vista o advento das mídias digitais no final do século passado, há uma tendência ainda maior de esquecimento.

Da "possibilidade de entrar em contato com alguma espécie de fabulação", está a entrega ao mundo da imaginação, da ficção, que leva o homem a sonhar e à fruição permitida pela literatura, a qual é direito de todo e qualquer indivíduo. "Por isso é que nas nossas sociedades a literatura tem sido um instrumento poderoso de instrução e educação, entrando nos currículos, sendo proposta a cada um como equipamento intelectual e afetivo", conforme Candido (1988).

Dessa forma, dentre as funções da escola, está a de resgatar e divulgar a cultura do seu meio, e um dos exemplares mais singulares culturalmente talvez seja o conto popular. A respeito disso, Cascudo (apud, SILVA, 2009, p. 234) afirma:

E mais: acoplada ao apagamento de tempo e lugar está a vasta circulação e a ampla disseminação dessas histórias. Isso é o que caracteriza o conto popular, por exemplo. Segundo Câmara Cascudo, as características do conto popular são exatamente: 'antiguidade, anonimato, divulgação e persistência'(Cascudo, s.d, p.8). 'É preciso que o conto seja velho na memória do povo, anônimo em sua autoria, divulgado em seu conhecimento e persistente nos repertórios orais. Que seja omisso nos nomes próprios, localizações geográficas e datas fixadoras do caso no tempo' (SILVA, 2009, p. 234).

Assim, escolhemos o (re) conto "Uma lição no fazendeiro", do livro Causos de Pedro Malasartes, escrito por Júlio Emílio Braz e ilustrado por Anelise Zimmermann, para desenvolver uma proposta de letramento literário em um 6. ${ }^{\circ}$ ano do ensino fundamental.

\section{FUNDAMENTAÇÃO TEÓRICA}

No segmento da Educação Básica, principalmente a do Ensino Fundamental, a divulgação do repertório folclórico pode ser feita por meio da literatura infantojuvenil. É extremamente importante que crianças e jovens entrem em contato com histórias, causos e lendas a que seus ascendentes tiveram acesso. Como afirmam Zilberman e Silva (1990, p. 27): 
acontecimentos e 'causos', passíveis de assuntar. Somos história na soma das histórias tecidas na cotidianeidade. Nos limites do mundo da oralidade e/ou na proximidade possibilitada pela escrita acontecemos e, consequentemente, passamos a existir.

Além disso, não devemos esquecer da formação do leitor que a literatura possibilita uma vez que "leva o leitor a refletir sobre a sua rotina e a incorporar novas experiências" (ZILBERMAN e SILVA, 1990, p. 19). Assim, para exercitarmos essa teoria na prática, escolhemos o personagem Pedro Malasartes.

Seu nome pode ser escrito: Pedro Malasartes, Malazartes, ou das Malasartes. Ficou bem conhecido e se tornou um personagem tradicional da cultura portuguesa e, posteriormente, da cultura brasileira. Essa figura era um exemplo da esperteza, da inteligência, da criatividade, mas não se sentia nenhum pouco culpado em usar a mentira e enganar as outras pessoas em proveito próprio. De acordo com o pesquisador da cultura nacional Câmara Cascudo, "Pedro Malasartes é figura tradicional nos contos populares da Península Ibérica, como exemplo de burlão invencível, astucioso, cínico, inesgotável de expedientes e de enganos, sem escrúpulos e sem remorsos" (apud BRAZ, 2011, p. 7). A menção mais antiga feita ao personagem é na cantiga 1132, do Cancioneiro da Vaticana, datado do século XIII e XIV:

\author{
Chegou Payo de Maas Artes \\ com seu cerame de chartes... \\ semelha-me busuardo \\ viindo en ceramen pardo... \\ log'ouve manto e tabardo.
}

Duas óperas brasileiras têm o personagem por protagonista: Malazarte, de Oscar Lorenzo Fernández e Graça Aranha, e Pedro Malazarte, de Mozart Camargo Guarnieri e Mário de Andrade. Na literatura, vários autores usaram o personagem e nos cinemas ele tomou corpo com "As Aventuras de Pedro Malasartes", de 1960, com Mazzaropi no papel principal, além de ter servido de mote para a composição da música caipira intitulada Pedro Malazartes, da dupla Zé Tapera e Teodoro.

Como podemos verificar, o personagem Pedro Malasartes é muito instigador em se tratando de cultura popular e oralidade. É e continua sendo inspiração para diversas formas artísticas como as músicas caipira e erudita, o cinema, o teatro, a própria literatura e suas várias manifestações em verso e prosa. É um patrimônio cultural que deve ser conhecido, reconhecido e difundido pela escola e, para isso, escolhemos os pressupostos teóricos da Sequência Básica de Cosson (2014), passando pelas etapas de leitura de Michelletti (2000) e Cosson (2014), rediscutidas por Corsi (2015). 
Para proceder à leitura do texto literário em questão, utilizaremos a proposta de Corsi (2015) que, para uma aula de Língua e/ou Literatura Francesas, propôs, em A narrativa literária francesa como suporte para o letramento do leitor aprendiz de FLE, uma junção das etapas descritas por Cosson (2014) antecipação, decodificação e interpretação e por Micheletti (2002) decodificação, análise e interpretação do enunciado, "julgando como indispensáveis a 'antecipação', a 'decodificação', a 'análise' e a 'interpretação'” (p. 34).

\title{
2.1 ANTECIPAÇÃO
}

Quanto à antecipação, Corsi (2015) observa que:

\begin{abstract}
Sendo a antecipação descrita com um momento de aproximação do leitor com o livro e sua materialidade física, pressupõe o conhecimento e reconhecimento de elementos componentes da obra a ser lida, como a capa, o título, o número de páginas ou mesmo o formato do livro" (p. 34, grifo nosso).
\end{abstract}

O livro Causos de Pedro Malasartes traz cinco histórias desse personagem. A escolhida "Uma lição no fazendeiro" está distribuída em 17 páginas de texto verbal e não-verbal, ou seja, não se trata de um conto curto. As imagens são bem coloridas e se alternam, ora ocupando parte da página, ora ocupando a página inteira. As imagens já são utilizadas desde a capa, que mostra um Malasartes alegre e jovem, seguido por três animais "amigos": uma galinha, um cavalo e um cachorro. As cores utilizadas são claras e agradáveis aos olhos de quem vê o livro pela primeira vez. Na contracapa, há a ilustração da personagem em seu cavalo, de costas, e explicação sobre ele, além de trecho opinativo sobre o estilo do autor Júlio Emílio Braz. Por tudo isso, consideramos que os elementos iniciais do livro permitem uma antecipação rica de significados do personagem e de hipóteses a serem ratificadas ou não na(s) história(s), contribuindo para despertar o interesse e curiosidade pela leitura da narrativa.

Terminada a nossa exposição sobre a antecipação, vamos à próxima etapa, a da decodificação. Para Corsi (2015, p. 34), a decodificação seria "uma significação inicial do texto embasada no conhecimento do sentido das palavras e das estruturas linguísticas em geral".

\subsection{LEITURA/ DECODIFICAÇÃO/ DECIFRAÇÃO}

Para Cosson (2014, p. 40), "entramos no texto através das letras e das palavras. Quanto maior é a familiaridade e o domínio delas, mais fácil é a decifração". Consideramos, em nosso trabalho, que a obra possibilitou na capa e, principalmente, na contracapa, elementos significativos para a leitura, uma vez 
que, como expusemos anteriormente, elenca informações sobre o personagem, como algumas características.

O texto "Uma lição no fazendeiro" é um conto popular. Contos populares (ou folclóricos) são narrativas passadas de geração em geração. Elas não têm autor conhecido. Cada história é aumentada e modificada à medida que vai sendo repetida. A autoria é atribuída ao povo - folk, em inglês. Daí se origina a palavra folclore. Muitos contos populares são bastante antigos. Passando de boca em boca, não eram escritos. Mantinham-se vivos graças à memória dos contadores de histórias.

Quanto aos elementos e estrutura narrativas, o conto é narrado em terceira pessoa, onisciente. O foco narrativo é de um narrador-observador, que apresenta o personagem e suas características ao leitor: "Desde pequeno, Pedro Malasartes nunca foi chegado ao trabalho. Gostava de andar pelas estradas e vilas buscando roda de gente para conversar, para trapacear ou simplesmente para não trabalhar" (p. 7). A narração ocorre como se o narrador estivesse conversando com o leitor e, em muitos momentos da história, dirige-se ao leitorouvinte: "Aposto que você deve estar se perguntando quem é afinal de contas esse tal de Malasartes, e - sabe de uma coisa? - ninguém tem lá uma mesma definição" (p. 7). Assim, a linguagem possui um tom coloquial associado a elementos literários como o da rima utilizada ao longo de muitos trechos, tornando partes da prosa poética: "E, conforme o tempo foi passando, Malasartes foi-se aborrecendo, foi-se invocando, até não suportar mais: com a fome apertando, atirou um pedaço de pau na cachorrinha. Coitadinha! Saiu em disparada e não havia nada que a fizesse parar. Gania e não queria sair debaixo da cama de seu dono" (p. 10, grifos nossos). Também há o uso do discurso direto ao longo de toda a história, tornando a leitura dinâmica.

Os personagens do conto são Pedro Malasartes - o personagemprotagonista, o fazendeiro - personagem antagonista, a esposa do fazendeiro, o irmão de Malasartes - João, e seu pai e mãe, citados pelo narrador. Durante o enredo, há a descrição dos personagens. A descrição física e psicológica do protagonista aparece em vários momentos: “ (...) Uns falam de um homem feito (...) um moleque esperto e brincalhão, nem criança nem muito grandão, que vive de suas astúcias (...)" (p. 7); "Na verdade, sempre levava dinheiro e comida para casa, mas tanto seus pais quanto seu irmão sabiam muito bem que tudo era fruto de suas trapaças e velhacarias" (p. 8); "Mas, depois de algum tempo, chateou-se, pois, querendo ou não, João era seu irmão. Ninguém fazia seu irmão de bobo e saía assim, até porque, em termos de esperteza com certeza ninguém lhe dava lição" (p. 10). Sobre os pais e o irmão, temos: "Seus pais eram muito idosos (...)"; "João, o irmão mais velho"; "_Eu prefiro morrer de fome!- repetia João, orgulhoso"; "Gente honesta que eram, acostumados a trabalhar duro e dignamente para ter o que comer, não aceitavam"; “_ Você tá é com inveja, pois eu arranjei trabalho e você não! _ Então vai, bobalhão... (p. 8). Sobre o fazendeiro: "E como malandro conhece malandro, bem sabia quem era o novo patrão de seu irmão: um fazendeiro muito rico e cheio de espertezas que se valia de toda espécie de acordos matreiros para não pagar a seus empregados ou aos infelizes que tinham o azar de bater a sua porta pedindo emprego" (p. 8). Sobre a esposa do fazendeiro: "(...) sempre mais sensata e há muito contrariada com a maneira como o marido lidava com seus empregados" (p. 21) 
O tempo é cronológico, apesar de indeterminado com relação à época. Como o próprio narrador-contador expõe no início (1. parágrafo): "A história é mais ou menos assim e, segundo dizem, se é certo que tem começo, não tem fim, pois a cada lugar que se vá, nova história certamente se vai ouvir sobre as aventuras muito engraçadas de Pedro Malasartes" (p. 7). No entanto, para marcar a passagem de tempo interno da história, há elementos linguísticos como marcadores temporais. São eles: "Tempos depois..." (p. 8); "Mas, depois de algum tempo ...", "Certo dia...", "E conforme o tempo foi passando..." (p. 10); "No dia seguinte..." (p. 12); “Na manhã seguinte..." (p. 14); “(...) no dia seguinte..." (p. 21).

O espaço predominante é a fazenda, local onde ocorrem todas as peripécias narradas na história: “(...) chegou Pedro à fazenda dizendo que precisava de um emprego". (p. 10).

Em relação à estrutura do enredo linear do conto, temos a apresentação ou equilíbrio inicial no início da narração apresentando o personagem principal, dando sequência quando João, o irmão mais velho precisa e decide arrumar um emprego para ajudar a suprir as necessidades da família: "Como todos tinham de comer em sua casa, João, o irmão mais velho, resolveu arrumar emprego numa fazenda" (p. 8). A partir dessa decisão e do emprego conseguido pelo irmão, começa a complicação quando o irmão volta para casa sem ter recebido pelo tempo trabalhado na fazenda, além de ter passado por várias atribulações, como “(...) quase morrer de trabalhar", “(...) ganhar a não ser dor nas costas”, “(...) mãos abanando e sem um tostão no bolso" (p. 8).

Assim, o ponto exato do conflito está no momento em que João vai trabalhar na fazenda, marcado pelo elemento linguístico "Certo dia..." (p. 10). Ao longo do enredo, há todas as astúcias de Pedro e do fazendeiro, um tentando enganar o outro, em uma disputa de quem é mais esperto, mais malandro. De um lado, Malasartes vingando o irmão, tentando dar uma lição no fazendeiro e, ao mesmo tempo, levando vantagem com as suas ações, como a de se livrar da cachorrinha para poder voltar à casa-grande antes e terminar o trabalho na roça; a de quebrar todo o carro de boi e colocá-los dentro da sala da casa, fazendo um enorme estrago; a de fingir que os porcos estavam afundados na lama; a de quando conseguiu uma grande quantia de dinheiro da mulher do fazendeiro, fingindo que este havia pedido etc. Por outro lado, o fazendeiro tentando enganar mais um empregado, não pagando pelo serviço obtido para obter lucro: " _ Não se pode recusar trabalho aqui. E, se ficar zangado, nada vai receber, pode até apanhar" (p. 10); "E ficou calado, pensando em que tipo de tarefa pegaria finalmente empregado tão matreiro" (p. 14). Assim, vai seguindo a história com várias tarefas as quais Malasartes tem de cumprir a mando do fazendeiro até chegar no momento em que o fazendeiro não aguenta mais as malandragens de Pedro, chegando ao auge do conflito.

O clímax, então, se dá quando o fazendeiro chega ao limite e decide tomar uma última atitude em relação ao empregado, chegando às últimas consequências, a de armar uma armadilha para tirar-lhe a vida: "Nesse momento, o fazendeiro chegou ao alpendre da casa-grande. Ao ver o vulto armado da mulher, confundiu-a com Malasartes e atirou" (p. 22). Como não consegue o seu intento, o fazendeiro negocia a saída de Pedro da fazenda. Este finge-se interessado em ficar, mas aceita o dinheiro oferecido pelo fazendeiro. Dessa forma, o desfecho é assim: "Naquele dia, Malasartes tornara-se um homem rico. 
Rico o bastante para sair pelo mundo atrás de mais confusão e aventuras. Mas isso, claro, é outra história..." (p. 23).

Cabe também à leitura, as páginas anteriores ao enredo. Estas contêm as informações técnicas e possuem pequenos desenhos que evidenciam o ambiente rural da personagem, como o de um chapéu (p. 3), o da galinha ciscando (p. 4), o do chapéu de novo e do cachorrinho (p. 5), tornando o contato com o livro novamente agradável. Já as páginas 6 e 7 mostram o personagem em ações que podem suscitar algumas de suas possíveis características, como pescando de forma incomum, uma vez que ele encontra-se deitado, "descansando", com a linha de pesca ao pé e, em seguida, correndo em fuga, com semblante arteiro. A contracapa traz um último desenho de Malasartes de costas, em seu cavalo, tocando violão, retirando-se de cena. Nela, também há um texto que abrange o conteúdo do livro, aborda sobre o autor: "reúne cinco das melhores histórias de Pedro Malasartes, contadas pela escrita engenhosa e cheia de artimanhas de Júlio Emílio Braz", origem do nome, e emite, resumidamente, juízo de valor acerca das suas peripécias.

\subsection{ANÁLISE}

Após termos passado pelo processo da leitura, temos a análise. De acordo com Corsi $(2015$, p. 34):

Esta etapa se dá quando o leitor faz as primeiras compreensões da materialidade do enunciado narrativo, compondo sentidos para o que se encontra no interior da obra, traçando um caminho para chegar à interpretação. Assim, quando o leitor ultrapassar o sentido intrínseco do enunciado pode desvendar suas potencialidades interpretativas, fazendo inferências relacionadas aos conhecimentos de mundo que possui e reconstruindo ou ampliando o sentido da narrativa.

Uma vez que a análise amplia o sentido da leitura, devemos nos ater a algumas observações pertinentes em relação ao tipo de narração do conto e à linguagem do autor. Portanto, ampliando o que abordamos na leitura, vemos um narrador que conhece as idiossincrasias do personagem e dos fatos narrados, o que é uma característica própria do conto popular, pois o enredo é contado e recontado de acordo com a visão do contador de histórias, figura essencial da literatura oral. A evidência disso está logo no 1ำ parágrafo, da página 7: "A história é mais ou menos assim e, segundo dizem, se é certo que tem começo, não tem fim, pois a cada lugar que se vá, nova história certamente se vai ouvir sobre as aventuras muito engraçadas de Pedro Malasartes".

Outro ponto evidente nesse trecho é o narrador/contador deixar claro que a história é contada de acordo com o que outros contadores disseram: "segundo dizem"; além de mostrar também outra característica do conto popular que, por ser transmitido de geração a geração, "se é certo que tem começo, não tem fim, pois a cada lugar que se vá (...)", modifica-se, perdendo ou ganhando novos 
elementos. Assim, há um indício metalinguístico na narração que produz um efeito de contação de história, um reavivamento da memória dos contos populares da literatura oral. Essa metalinguagem aparece também no momento final da história: "Naquele dia, Malasartes tornara-se um homem rico. Rico o bastante para sair pelo mundo atrás de mais confusão e aventuras. Mas isso, claro, é outra história..." (p. 23).

Um outro elemento da linguagem é como o discurso direto foi utilizado. Ao usar o discurso direto, há um recurso gráfico que evidencia a voz de Malasartes por meio de letras maiores e de cor diferente (azul) dos demais personagens. A do fazendeiro, a partir do momento que sua relação com o protagonista torna-se insustentável, também passa a ter alguns discursos evidenciados em letras grandes e de cor diferente. Ao retratar essas falas de modo incomum, percebemos as forças opostas de protagonista e antagonista em disputa durante o enredo, além de ressaltar a quem está lendo a história o momento de tornar a fala de Malasartes mais enfática, dando atenção maior ao acontecimento que envolve a fala em questão.

Além disso, consideraremos a análise por meio das ilustrações feitas na obra por Anelise Zimmermann. Todas são muito elucidativas em relação ao enredo do conto. Conforme a história vai sendo contada, elas aparecem nas páginas do livro, ocupando página inteira ou parte da página, reproduzindo em sentido literal os acontecimentos. No momento da antecipação, o leitor já percebe essa distribuição feita na narrativa, uma vez que muitas ilustrações denotam as características dos personagens e suas atitudes na história, como a da página 20, em que o fazendeiro e sua mulher estão brigando em decorrência das malandragens/espertezas do protagonista. Vale ressaltar a ilustração da página 9 , em que vemos o irmão de Malasartes ao fundo, pequeno, chegando cansado e derrotado após o trabalho na fazenda, e Pedro em primeiro plano na página, sentado/deitado debaixo de uma árvore, tocando violão. $O$ contraste feito pela ilustração é significativo em relação, como elencado anteriormente, às características e ações dos personagens. Como evidencia Camargo (2012, p. 2):

Toda a história da arte mostra que a imagem pode dizer algo, sem precisar acompanhar um texto. Toda imagem diz alguma coisa, por si mesma. Por isso, não se pode reduzir o sentido da ilustração a uma espécie de tradução do texto, nem reduzir o significado da imagem à identificação do ser que a imagem representa. Por outro lado, os significados do texto se projetam sobre a imagem, assim como os significados da imagem se projetam sobre o texto. É uma interação de mão dupla.

Voltando à análise de nosso personagem principal, uma figura tão emblemática e controversa, não podemos deixar de ressaltar um aspecto que acreditamos ser relevante em relação à sua constituição histórica. Note-se que, na maioria das caracterizações de Malasartes, este aparece como esperto, cínico, sem escrúpulos e remorsos. Contudo, não se trata de único viés caracterizador, uma vez que, de acordo com Coelho (1987, p. 73), “(...) as tramas narrativas se desenvolvem em torno de três situações básicas: de trabalho, de casamento, de 
exploração do homem pelo poder". Observamos claramente isso no diálogo que segue abaixo (p. 21), entre o fazendeiro e a sua mulher. Esta, correta e honesta em relação à atitude a ser tomada acerca do empregado, diferentemente do marido, que mostra se preocupar com a opinião dos outros, provavelmente, outros fazendeiros que, se vão questionar a sua atitude de pagar o empregado, devem praticar o mesmo com os seus. Outro forte indício de desmando e abuso de poder é quando o fazendeiro parece não se preocupar com a polícia ao decidir matar Malasartes, o que mostra a impunidade imperiosa do contexto da história, não deixando de existir em nosso contexto atual.

Eu vou acabar pobre e arruinado se continuar com esse empregado por aqui-admitiu.

- Pague a ele e mande-o embora, homem! - sugeriu sua mulher, sempre mais sensata e há muito contrariada com a maneira como o marido lidava com seus empregados.

_Quê? - trovejou o fazendeiro. _ Nem pensar!

_ Por que não? Seria mais fácil do que...

_ Eu acabaria virando motivo de chacota de todo mundo!

_ Seria melhor...

_ Deve ter outro jeito, tem de ter...

Que jeito, homem?

O fazendeiro sorriu misteriosamente.

_Eu já sei... - disse.

_ Ah, é? - perguntou sua mulher enquanto lhe esfregava as costas.

_ Matá-lo, é claro.

- Mas... mas...

O fazendeiro decidiu mata-lo; sua mulher assustou-se.

_ Mas e a polícia, homem? - quis saber, nervosa e ainda mais preocupada.

A gente pensa nisso depois - garantiu o fazendeiro [...] (p. 21)

\subsection{INTERPRETAÇÃO}

Após a análise acima, partimos para a interpretação. Para Corsi (2015), interpretação acontece quando o leitor ultrapassa "o sentido intrínseco do 
enunciado (...) fazendo inferências relacionadas aos conhecimentos de mundo que possui (...) reconstruindo ou ampliando o sentido." Nesse momento,

\begin{abstract}
o leitor entende o que escreveu o autor e que se traduz na linguagem composta de enunciados contendo sentidos oferecidos por determinada comunidade. Nesse sentido, considera-se o contexto da composição da obra e de sua recepção, posto que autor e leitor possuem conhecimentos de mundos sociais formados de vivências e ideologias determinadas por fatores diversos (p. 34-35).
\end{abstract}

O conto "Uma lição no fazendeiro", portanto, refere-se à exploração dos fracos pelos fortes e à astúcia/esperteza dos explorados para escaparem ou vencerem os exploradores. Em nosso contexto capitalista, cabe àquele que necessita do trabalho para a sua subsistência, aceitar o que convém por quem oferece o emprego, sem se importar com as condições de trabalho oferecidas e se o salário será o suficiente para uma vida digna. O necessitado deve aceitar o que lhe é imposto sem questionar, pois quem questiona o status quo concebido não merece crédito bem como o mínimo necessário: um emprego ou trabalho.

Devido a isso e pelo que percebemos do conto estudado, Malasartes é a voz daqueles que não conseguem, nos diversos percalços cotidianos reais, vencer o mais forte - o explorador. A imaginação criadora de nossa gente, ao longo de séculos, construiu um personagem redentor das mazelas, muitas vezes, intransponíveis de uma dura realidade existente em diversos momentos históricos. Indubitavelmente, por isso, Malasartes tenha sobrevivido durante tanto tempo, em diferentes gerações, cabendo à literatura e à escola não deixar que seu valor e sua memória sejam obscurecidos.

\title{
3. ETAPAS DA SEQUÊNCIA BÁSICA
}

Este trabalho foi produzido tendo como um dos intuitos o de abordar, por meio da Sequência Básica proposta por Cosson (2014), um dos contos populares do livro Causos de Pedro Malasartes, do escritor Júlio Emílio Braz e da ilustradora Anelise Zimmermann e, assim, propor o letramento literário do conto "Uma lição no fazendeiro". De acordo com o pesquisador, a sequência básica está dividida nas seguintes etapas: motivação, introdução, leitura e interpretação (interna e externa).

A motivação visa preparar o aluno para a leitura do texto e essa preparação pode ser feita de diversas formas, como envolver atividades de leitura, escrita e oralidade. Pretende despertar a consciência de que leitura envolve saber e prazer, além de objetivar a interação com a estrutura e a temática do texto, preparando o aluno-leitor para uma agradável recepção do material a ser lido (COSSON, 2014). Assim, para a etapa da motivação envolvendo a oralidade, pensamos em começar com a seguinte pergunta: Seus avós, pais ou outra pessoa da família já contou alguma história pra você? Se contou, qual foi essa história? 
O professor interage com a turma, verificando se as histórias se repetem e quais são diferentes. Certamente, os alunos participarão e recontarão as histórias ouvidas na família. Para continuar a etapa da motivação envolvendo a escrita, o professor solicitará uma atividade de pesquisa aos alunos para eles trazerem na aula seguinte. A pesquisa consistirá em os alunos perguntarem aos seus pais se quando estes eram crianças se alguém da família Ihes contava histórias. Esse alguém pode ser os avós, pais, etc. Eles registrarão a história no caderno e depois poderão comparar em sala de aula com os colegas. Será que as histórias que seus pais Ihes contam são iguais às que os seus próprios pais ouviam quando crianças?

Após a discussão da pesquisa e da comparação das histórias, a professora mostrará o vídeo em que o seu pai conta uma das histórias que ela ouvia quando criança. Assim, resumidamente, temos as seguintes atividades de motivação: a) escuta das histórias que os alunos conhecem; b) pesquisa das histórias que os pais ouviam; c) vídeo com uma história de Malasartes.

Encerrada a motivação, seguimos para a introdução, que consiste na apresentação do autor e da obra a fim de permitir que o aluno a receba, segundo Cosson (2014), de maneira positiva. Pode "enfatizar as características dos autores e das obras a serem lidas" (p. 59) e incentivar o questionamento das escolhas feitas e das razões que levaram a fazê-lo em lugar de outras. Cabe ao professor falar da obra e de sua importância naquele momento, justificando sua escolha ( $p$. 60). No caso do nosso trabalho, temos por objetivo resgatar a importância dos "causos", ou seja, das estórias orais contadas e recontadas de geração em geração, seu possível significado à época e sua ressignificação no contexto atual.

Cosson (2014) também afirma que cabe ao professor apresentar a obra fisicamente ao aluno. Chamar a atenção para a leitura da capa, da orelha e de outros elementos paratextuais que introduzem uma obra. Coletivamente, deve levantar hipóteses sobre o texto e incentivá-los a comprová-las ou recusá-las depois da leitura da obra. Assim, a introdução seria feita da seguinte forma:

1) Apresentação e exploração dos elementos paratextuais do livro: capa da 1. ${ }^{a}$ edição de 2011. Perguntamos aos alunos:

a) O que vocês veem nas imagens da capa?

b) De acordo com as imagens, quais características psicológicas e comportamentais vocês atribuiriam a esse garoto?

c) Como deve ser o cotidiano (a rotina) dele?

d) Onde ele mora?

e) Ele tem família? Se tem, como você acha que é?

f) A história que nós vamos ler, como vocês viram, é do livro "Causos de Pedro Malasartes". Alguém sabe o que é um "causo"? Você já ouviu um "causo"? (Nessa pergunta, retomamos as atividades da motivação, em que introduzimos a leitura por meio da escuta de histórias e da pesquisa feita com os pais. Espera-se que os alunos relacionem a primeira atividade com a resposta à pergunta. Ocorrendo ou não a relação, o professor explica o que são causos e que as histórias ouvidas e recontadas podem ser assim classificadas).

g) Vimos, então, que causo é uma história transmitida oralmente. É muito difícil dizer quem inventou e quando alguém começou a contá-la. 
Por isso, na capa do livro está escrito reconto. Alguém sabe o que é reconto? E conto? Se conto é também uma história assim como o causo, então reconto seria... (os alunos levantam hipóteses e o professor complementa) ... uma história ouvida e contada novamente ... e novamente. Então, significa que o autor, Júlio Emílio Braz, ouviu de alguém, que ouviu de alguém, que também ouviu de alguém e vai contar para nós. Provavelmente, ele deve ter ouvido de seu pai, que ouviu do seu pai, que ouviu... Enfim, assim são os causos, as histórias orais. E já que estamos falando do autor, que tal conhecê-lo? Nessa parte, seria interessante expor aos alunos sobre o escritor Júlio Emílio Braz. As questões poderiam ser:

a) Você já ouviu falar do escritor Júlio Emílio Braz? Sabe de onde ele é?

b) Já leu algum livro dele? Sabia que ele já escreveu mais de 20 livros? Já escreveu textos para a televisão, como programas de humor e novelas. (Podemos ler as informações sobre o autor que estão no final do livro, página 48).

c) Depois que conhecemos um pouco sobre o autor, vamos ao livro. Neste livro, há cinco "causos" de Pedro Malasartes. Nós vamos ler o "Lição no fazendeiro". O que significa a palavra "lição"? Pelo título, o que você acha que acontecerá nessa história, ou seja, que "lição" será essa? Quem vai dar "uma lição" em quem? (O professor pode ir registrando as hipóteses no quadro para depois compará-las).

d) Que tal agora, depois que vocês disseram qual pode ser essa "lição" que o personagem Pedro Malasartes aplicará no fazendeiro, nós tentarmos recriar a história de acordo com as imagens do livro!? (Nessa parte, o professor mostrará as ilustrações feitas por Anelise Zimmermann [páginas 4, 5, 6, 9, 11, 12, 13, 14, 16, 17, 18, 19, 20 e 23] e os alunos oralmente criarão um enredo para o causo). Uma vez que os alunos participem ativamente dessa atividade, cujas ilustrações desempenham papel fundamental em se tratando de literatura voltada ao público infanto-juvenil, seria pertinente também comentar sobre a ilustradora e mostrar uma imagem dela, assim como fizemos em relação ao escritor.

A terceira parte de nossa sequência básica é a leitura. Segundo Cosson (2014), pode tratar-se de um acompanhamento através de uma simples conversa; de leitura de textos com o mesmo tema; leitura conjunta de um capítulo. Para o nosso trabalho, utilizaremos uma das sugestões de Cosson (2014), a da leitura de textos do mesmo tema. No caso, pensamos em um texto que trata do mesmo personagem, pois na página 7 do livro há a descrição de Pedro Malasartes de acordo com o folclorista Luis da Câmara Cascudo. Como é uma descrição com termos desconhecidos para os alunos, poderíamos, antes de explorá-la, ouvir uma música caipira (lembrando que a música caipira é um patrimônio cultural com grande influência da oralidade, principalmente aquelas que têm como mote histórias/causos transmitidos de geração para geração). A música sugerida é intitulada Pedro Malazartes, da dupla Zé Tapera e Teodoro, cuja letra segue abaixo: 
Não sei a origem do seu nascimento no meu pensamento ele veio de marte,

talvez ele seja de outro planeta pior que o capeta

só fazia arte,

seu tipo gozado seu jeito manhoso ficou fabuloso por

toda as parte,

seu nome completo não foi conhecido mas seu apelido é Pedro Malazarte.

Assim era Pedro muito inteligente não tinha parente $e$ nem destino certo,

não era assassino nem homem covarde dizia a verdade era muito esperto,

existe um ditado que todas maldades mais cedo ou mais tarde será descoberto,

as artes do Pedro se alguém descobria o Pedro já ia pra outro deserto.

Em todos os lugares que ele chegava dizia que estava sem colocação, com muita conversa num papo danado já era ajustado com muita atenção, tudo que mandava ele atendia mas tudo fazia na sua opinião, mas com pouco tempo era despachado se não o empregado virava patrão.

Assim foi vivendo na base da trama e a sua fama se esparramou, até a princesa de um grande reinado pelo seu agrado se apaixonou, sabendo a verdade o rei soberano traçou vários planos mas não adiantou, o resto da história eu conto de uma vez com a filha do rei o Pedro se casou.

(https://www.letras.mus.br/ze-tapera-teodoro/1761865/)

Discutiremos com os alunos sobre o conteúdo da letra da música- o personagem, suas características e ações -, e da possibilidade dessas características confirmarem-se ou não em decorrência da leitura do texto, com atenção especial à terceira estrofe que remete ao enredo do conto e ao primeiro verso da letra que alude à transmissão oral "Assim foi vivendo na base da trama e a sua fama se esparramou".

Aqui, teríamos o que Cosson denomina de intervalo: "Um exemplo é a leitura de outros textos menores que tenham alguma ligação com o texto maior, funcionando como uma focalização sobre o tema da leitura e permitindo que se teçam aproximações breves entre o que já foi lido e o novo texto" (COSSON, 2014, p. 63). Após o trabalho com a música, faríamos a leitura da definição citada anteriormente sobre o personagem e que se encontra na página 7 do livro: 
Pedro Malasartes é figura tradicional nos contos populares da Península Ibérica, como exemplo do burlão, invencível, astucioso, cínico, inesgotável de expedientes e de enganos, sem escrúpulos e sem remorsos... (Dicionário do Folclore Brasileiro, de Luis da Câmara Cascudo, apud Braz, 2011, p.6).

Nessa parte, o professor pode utilizar o dicionário com os alunos para pesquisar o significado dos vocábulos desconhecidos e comparar os adjetivos atribuídos na definição de Cascudo com os da música. Posteriormente, a comparação última seria com as características apresentadas pelo personagem no decorrer do conto "Uma lição no fazendeiro". Também seria interessante mostrar aos alunos uma imagem da Península Ibérica, localizando-a, principalmente em relação ao nosso espaço geográfico.

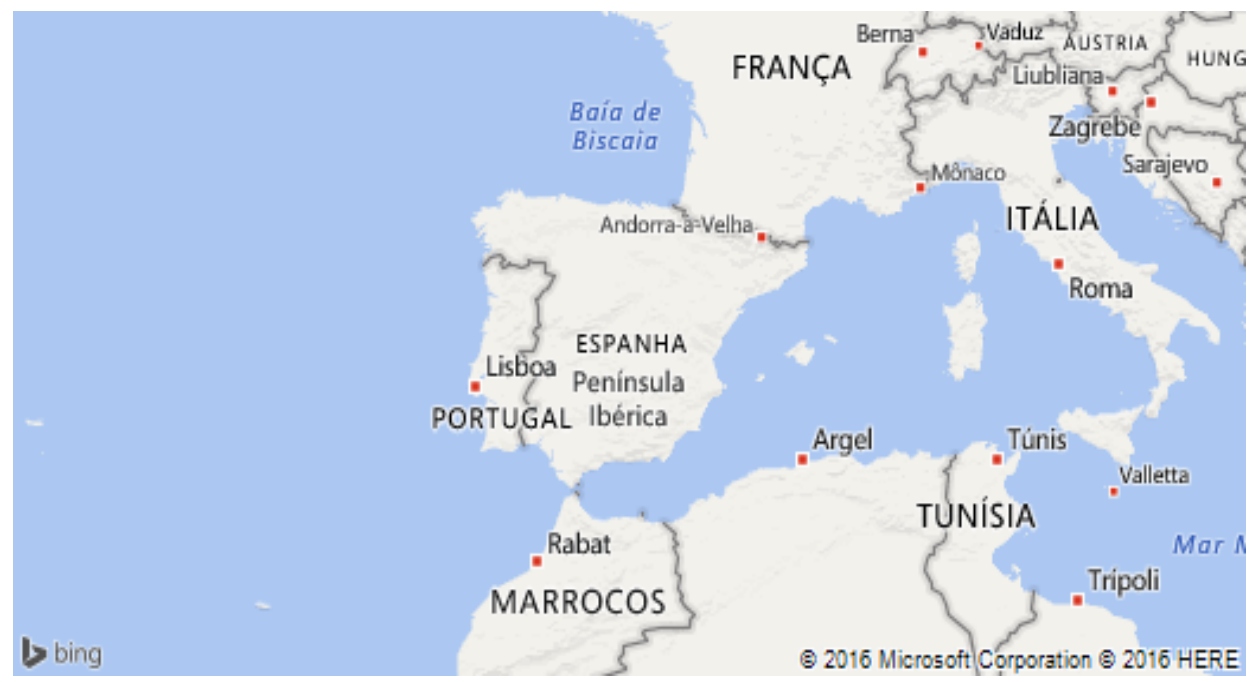

(https://www.bing.com/search?q=Mapa+Da+Pen\%c3\%adnsula+lb\%c3\%a9rica\&FORM=R5FD1

Após o trabalho inicial dessa etapa, iniciaremos a leitura do reconto "Uma lição no fazendeiro", de forma expressiva (em voz alta) feita pelo professor em tom de "contação", uma vez que é narrada assim. Em seguida, exploraremos os elementos narrativos e enredo do conto.

a) Quem participa desta história? Há nomes próprios citados na obra?

b) Onde as personagens estão?

c) Você saberia dizer se é uma história atual? Como você sabe disso? Há alguma indicação no texto? Quando? 
d) Quem conta esta história? É uma personagem? Como você descobriu isso?

e) Quem é o protagonista, ou seja, a personagem principal da narrativa?

f) Quem é o antagonista?

g) Quem são as personagens secundárias?

h) Retire do texto os termos (adjetivos) que caracterizam as personagens de Pedro e do fazendeiro.

i) Na história, quando o personagem de Pedro Malasartes fala, as letras são diferentes do restante do texto. Como são essas letras e por que foram escritas de modo diferente?

j) Retire do texto trechos que iniciem as partes da narrativa: apresentação ou situação inicial, complicação/conflito (situação-problema), clímax e desfecho, de acordo com as explicações abaixo:

Apresentação: é o começo da história, no qual apresenta(am)-se a(as) personagem(ns) e suas características, o espaço em que se movimenta(am), as relações que mantêm entre si e, às vezes, o tempo e o espaço, conforme exemplo: um homem caminha à noite por uma estrada escura. Situando o leitor diante da história que irá ler.

Complicação: rompe-se o equilíbrio do estado inicial; surge $(\mathrm{m}) \mathrm{o}(\mathrm{s})$ conflito(s) e começam a ocorrer os acontecimentos, as ações nos episódios, que, encadeados, conduzem a narrativa a um ponto máximo de tensão.

Clímax: o conflito chega ao seu ponto máximo de tensão, resultante da convergência dos vários conflitos vividos pelas personagens. O clímax é o ponto de referência para as outras partes do enredo, que existem em função dele. De modo geral, o clímax situa-se próximo do fim e, por vezes, com ele identificado.

Desfecho ou Desenlace: corresponde à situação final, à solução dos conflitos. Chega-se, como na situação inicial, a um novo equilíbrio. Há muitos tipos de desfecho: surpreendente, feliz, trágico, cômico etc.

Quanto à interpretação, Cosson (2014, p. 64) afirma que "a interpretação parte do entretecimento dos enunciados, que constituem as inferências, para chegar à construção do sentido do texto, dentro de um diálogo que envolve autor, leitor e comunidade". $\mathrm{O}$ autor divide-a em dois momentos: um interior e outro exterior.

\subsection{INTERPRETAÇÃO INTERNA}

"Certo dia, chegou Pedro à fazenda dizendo que precisava de um emprego. O fazendeiro, matreiro que só, admitiu que realmente precisava de empregados, mas só aceitava aqueles que concordassem com certas condições” (p. 10).

a) O trecho acima resume o tema do texto: a situação de exploração do patrão para com o empregado; de alguém em situação de superioridade em relação a outro. Porém, Malasartes, como percebemos no texto, usou de 
esperteza para contornar a situação. Reescreva as atitudes de Pedro para enganar o fazendeiro, de acordo com a ordem em que elas aparecem na história.

b) Atualmente, há mais pessoas morando em áreas rurais ou urbanas? Por quê?

c) O irmão de Pedro Malasartes, João, estava desempregado e a família passava privações (necessidades). Há muitas pessoas na mesma situação que ele hoje? Por quê?

d) Devido à necessidade de sobrevivência, João aceita trabalhar sem direito a reclamar e sem receber pelo seu trabalho. Para você, ele foi explorado pelo fazendeiro? Por quê?

e) Há pessoas que são submetidas às mesmas condições de exploração que João? Por quê?

f) Na história, Pedro dá uma lição no fazendeiro que prejudicou João. Você acha que a atitude dele foi correta? Você, nessa situação, faria o quê?

g) Hoje, quando alguém submete outra pessoa a trabalhar em condições degradantes (trabalho escravo), há algum tipo de punição?

\subsection{INTERPRETAÇÃO EXTERNA}

Para a concretização da interpretação externa, sugerimos três atividades:

1) O conto "A lição no fazendeiro" termina assim: "Naquele dia, Malasartes tornara-se um homem rico. Rico o bastante para sair pelo mundo atrás de mais confusão e aventuras. Mas isso, claro, é outra história...” Agora que Malasartes está rico e saiu pelo mundo, que tal escrever o que acontecerá com ele, criando mais uma história de confusão e aventuras!?

2) Trabalho em equipe: pesquisar outros causos de Pedro Malasartes, adaptar o texto para ser dramatizado, filmar e apresentar para a turma. A adaptação pode ser divulgada depois na internet, como alguns exemplos que podem ser encontrados nos seguintes endereços eletrônicos:

https://www.youtube.com/watch?v=acEioi 8Hno

https://www.youtube.com/watch?v=RSP pl2TQFk

https://www.youtube.com/watch?v=Syq2DAHbKp0

3) Solicitar uma pesquisa sobre trabalho infantil e trabalho escravo e debater o assunto a partir de dados e material pesquisados: textos, vídeos, documentário, reportagem etc. Inserir o assunto no contexto social dos alunos.

\section{CONSIDERAÇÕES FINAIS}

Reafirmamos em nosso trabalho o objetivo de resgatar a importância dos "causos", ou seja, das estórias orais contadas e recontadas de geração em geração, seu possível significado à época e sua ressignificação no contexto atual. 
Ademais, consideramos urgente repensar nossa prática, aprimorando-a frente aos desafios educacionais contemporâneos, dentre eles o letramento literário. Embora a atividade proposta tenha sido suscitada a partir de nosso contexto de aperfeiçoamento, urge colocarmos que o objetivo de incentivar a leitura é nosso alvo constante, além de intencionarmos desenvolver novos conhecimentos linguísticos, enciclopédicos e interacionais com a literatura, a fim de formar sujeitos que aprimorem a leitura, dialogando cada vez mais com diversos discursos e, consequentemente, refletindo criticamente sobre. 


\title{
Literature and memory: a proposal of literary literacy to the popular tale in the Middle School
}

\begin{abstract}
In the elementary school segment, dissemination of the folkloric repertoire can occur through the literature of children and youth, since it is important that children and young people come into contact with the stories, causes and legends that their ancestors had access to. Therefore, the present work has the objective of recovering the importance of the causes, that is, the oral narratives counted and recounted from generation to generation, their possible meaning at the time and their signification in the current context. Being one of the functions of the school to value and spread oral culture, one of the most singular examples is the popular tale. In order to contribute to the rescue of memory and literary history, we chose the (re) tale "A Lesson in the Farmer", from the book Causos de Pedro Malasartes, written by Julio Emílio Braz and illustrated by Anelise Zimmermann, to develop a proposal of literary literacy in the middle school. The theoretical basis of this work was based on Zilberman and Silva (1990), Silva (2009), Michelletti (2000), Cosson (2014) and Corsi (2015).
\end{abstract}

KEYWORDS: Literary literacy. Popular culture. Teaching. (Re) tale. 


\section{REFERÊNCIAS}

BRAZ, Júlio Emílio. Causos de Pedro Malasartes. $1^{\mathrm{a}}$ edição, São Paulo: Cortez, 2011.

CANDIDO, Antonio. O direito à literatura, págs. 169-191. In: Vários Escritos. Editora Ouro Sobre Azul, 2004.

COELHO, Nelly Novaes. A literatura infantil: história, teoria, análise. 4. ${ }^{a}$ edição, São Paulo: Quíron, 1987.

CORSI, Margarida da Silveira. A narrativa literária francesa como suporte para o letramento do leitor - aprendiz de FLE. Maringá, Eduem, 2015.

COSSON, Rildo. Letramento Literário: teoria e prática. $2^{\mathrm{a}}$ edição. São Paulo: Contexto. 2014.

MICHELLETI, Guaraciaba. Leitura e construção do real: o lugar da poesia na ficção. São Paulo, Cortez, 2000.

SILVA, Celso Sisto. A literatura popular: silêncios e murmúrios na história da literatura brasileira. Letrônica, Porto Alegre, v.2, n.2, 2009.

ZILBERMAN, Regina e SILVA, Ezequiel Theodoro. Literatura e Pedagogia: ponto e contraponto. Porto Alegre: Mercado Aberto, 1990.

Endereços eletrônicos:

http://www.culturainfancia.com.br/portal/index.php?option=com content\&view =article\&id=61:uma-conversa-sobre-ilustracao\&catid=39:artesplasticas\&Itemid=61. Acesso em 23 de julho de 2012.

http://jangadabrasil.com.br/bibliografia/bibliografiace.htm\#cascudo

http://comdedineri.blogspot.com.br/2011/04/sugestoes-de escritoresas.html

http://udesc.academia.edu/AneliseZimmermann 
https://www.binq.com/search?q=Mapa+Da+Pen\%c3\%adnsula+lb\%c3\%a9rica\&F $\underline{O R M=R 5 F D 1}$

https://www.letras.mus.br/ze-tapera-teodoro/1761865/

https://www.youtube.com/watch?v=acEioi $8 \mathrm{Hno}$

https://www.youtube.com/watch?v=RSP pl2TQFk

https://www.youtube.com/watch?v=Syq2DAHbKp0

Recebido: 29 abr. 2017

Aprovado: 07 set. 2017

DOI: $10.3895 /$ rl.v19n26.5853

Como citar: SURIANO, Edivana Cássia Munhoz; CORSI, Margarida da Silveira. Literatura e memória: uma proposta de letramento literário para o conto popular para o ensino fundamental. R. Letras, Curitiba, v. 19 , n.

26, p. 86-105, set. 2017. Disponível em: <https://periodicos.utfpr.edu.br/rl>. Acesso em: XXX

Direito autoral: Este artigo está licenciado sob os termos da Licença Creative Commons-Atribuição 4.0 Internacional.

(c) (1) 